Степаненко О. І., к.е.н., доцент Київський національний економічний університет імені Вадима Гетьмана м. Київ, Украӥна

DOI: https://doi.org/10.30525/978-9934-26-036-0-27

\title{
СУЧАСНІ НАУКОВО-ПРАКТИЧНІ ПІДХОДИ ДО ОЦІНКИ ЛІКВІДНОСТІ ПІДПРИЕМСТВА
}

Категорія ліквідності відіграє вагому роль при формуванні виваженої фінансової політики підприємства на будь-якому етапі його розвитку, особливо в період економічної кризи. Недостатня ліквідність означає, що суб'єкт господарювання не може 
скористатися новими вигідними комерційними можливостями, тобто він немає свободи вибору, і це значно обмежує дії керівництва. Також низька ліквідність свідчить, що підприємство немає достатнього запасу грошових коштів для оплати своїх поточних зобов'язань. Це може призвести до інтенсивного продажу довгострокових вкладень i активів, а в найгіршому випадку - до неплатоспроможності й банкрутства.

Для власників підприємства недостатня ліквідність може означати зменшення прибутковості, часткову або повну втрату капіталу. А якщо власники несуть обмежену відповідальність, їх збитки можуть перевищити початкові вкладення. 3 позиції кредиторів - низька ліквідність у боржника може свідчити про затримку у сплаті основної суми боргу. Негативний поточний стан ліквідності може також вплинути на його взаємовідносини 3 контрагентами (покупцями, постачальниками), викликати неспроможність виконувати умови контрактів та призвести до втрати ділових зв'язків. Якщо господарюючий суб'єкт не має можливості погасити свої поточні зобов'язання у визначені терміни їх оплати, його подальше існування ставиться під сумнів. А тому оцінка ліквідності займає важливе місце в аналізі фінансового стану підприємства.

Цілісну науково-практичну концепцію аналізу ліквідності підприємства обгрунтовує професор Парасій-Вергуненко I.M., яка побудована на знаннях про об'єктивну економічну сутність даного явища, виділяє реальні об'єкти, відповідні їм завдання та методики ïх вирішення. 3 позиції науковця, ліквідність - це «... здатність підприємства швидко перетворювати свої активи на грошові кошти без втрати (або з мінімальною втратою) їхньої ринкової вартості з метою своєчасного виконання своїх зобов'язань» [1, с. 84]. В реаліях сьогодення дане трактування є найбільш точним, оскільки саме вартість активів, а також ділова активність підприємства впливають на швидкість реалізації активів.

Ліквідність за своїм змістом є комплексним поняттям, і за класичним підходом включає такі категорії: ліквідність активів, ліквідність балансу, ліквідність підприємства. У своїй концепції 
професор Парасій-Вергуненко I.M. пропонує та науково обгрунтовує введення поняття «ліквідність пасивів», під яким слід розуміти «... здатність підприємства (наявність можливості) негайно отримувати грошові кошти для виконання своїх поточних зобов'язань за рахунок збільшення інших зобов'язань довгострокового характеру» [1, с. 85]. Такий підхід автор пояснює тим, що платоспроможність підприємства залежить не тільки від ліквідності активів і балансу, а й здатності швидко залучати кошти (наприклад, через отримання кредитів) для iї підтримки.

Цікавою та досить виваженою $є$ позиція науковця щодо ліквідності активів (як категорії), яку пропонується розглядати в двох аспектах виміру: зі статичного підходу - як запас, 3 динамічного - як потік. Ліквідність як запас включає визначення можливості підприємства виконувати свої зобов'язання перед кредиторами в конкретний момент часу через зміну структури активів на користь їхніх високоліквідних статей за рахунок наявних невикористаних резервів. Натомість, ліквідність як потік характеризується 3 позиції динаміки, що передбачає встановлення здатності підприємства протягом певного періоду підвищувати ліквідність або не допускати зниження доступного, об’єктивно необхідного ¥ї рівня за рахунок ефективного управління оборотністю активів, пасивів, залучення додаткових коштів [1, с. 86].

Обсяги та ступінь покриття активами відповідних груп зобов'язань здійснюється через оцінку ліквідності балансу. Традиційно виділяють чотири групи активів і пасивів, але при цьому прослідковуються розходження у віднесенні тих чи інших активів (пасивів) до певних груп. Це пов'язано з ігноруванням об'єктивної логіки ліквідності, а також терміновості, що призводить до необ'єктивних результатів та викривлення інформації щодо ліквідності балансу господарюючого суб'єкта.

Сучасний підхід до групування активів і пасивів балансу для оцінки його ліквідності пропонується професором Калабуховою С.В., який розглядається, через призму правил 
фінансових пропорцій, що забезпечують користувачів інформацією про «нормальний» фінансовий стан підприємства, та якими керуються фінансисти Свропи.

Таблиця 1

Групування активів та пасивів для оцінки ліквідності балансу

\begin{tabular}{|c|c|c|c|c|c|c|c|}
\hline \multicolumn{4}{|c|}{$\begin{array}{l}\text { Класичний підхід } \\
\text { [1, с. 87-88; 3, с. 142-144; } \\
\text { 4, с. 121-124] }\end{array}$} & \multicolumn{4}{|c|}{$\begin{array}{c}\text { Науково-практичний підхід професора } \\
\text { Калабухової С.В. для застосування } \\
\text { «золотого правила» ліквідності } \\
{[2, \text { с. } 149]}\end{array}$} \\
\hline \multicolumn{2}{|c|}{ Група активів } & \multicolumn{2}{|c|}{ Група пасивів } & Група актив & & \multirow{2}{*}{\multicolumn{2}{|c|}{$\begin{array}{r}\text { Група пасивів } \\
\text { л більше } 12 \text { місяців }\end{array}$}} \\
\hline \multirow[b]{2}{*}{$\begin{array}{l}\text { Високо- } \\
\text { ліквідні }\end{array}$} & \multirow[b]{2}{*}{$\mathrm{A}_{1}$} & \multirow[b]{2}{*}{$\begin{array}{l}\text { Найбільш } \\
\text { термінові }\end{array}$} & \multirow[b]{2}{*}{$\Pi_{1}$} & \multicolumn{2}{|c|}{ Операційний цикл більше 12 місяців } & & \\
\hline & & & & \multirow[b]{2}{*}{$\begin{array}{c}\text { Важколіквідні } \\
\text { активи }\end{array}$} & \multirow[b]{2}{*}{$\mathrm{A}_{4}$} & $\begin{array}{c}\text { Постійний } \\
\text { капітал }\end{array}$ & $\Pi_{4}$ \\
\hline $\begin{array}{l}\text { Швидко } \\
\text { ліквідні } \\
\text { (середньо } \\
\text { ліквідні) } \\
\end{array}$ & $\mathrm{A}_{2}$ & $\begin{array}{l}\text { Коротко- } \\
\text { строкові }\end{array}$ & $\Pi_{2}$ & & & $\begin{array}{l}\text { Довгострокові } \\
\text { зобов'язання }\end{array}$ & $\Pi_{3}$ \\
\hline \multirow[b]{2}{*}{$\begin{array}{l}\text { Повільно } \\
\text { ліквідні } \\
\text { (низько } \\
\text { ліквідні) }\end{array}$} & \multirow[b]{2}{*}{$\mathrm{A}_{3}$} & \multirow[b]{2}{*}{$\begin{array}{l}\text { Довго- } \\
\text { строкові }\end{array}$} & \multirow[b]{2}{*}{$\Pi_{3}$} & \multicolumn{4}{|c|}{ Операційний цикл менше 12 місяців } \\
\hline & & & & $\begin{array}{c}\text { Повільно } \\
\text { ліквідні активи } \\
\text { (від } 6 \text { до } \\
12 \text { місяців) }\end{array}$ & $\mathrm{A}_{3}$ & \multirow{2}{*}{$\begin{array}{l}\text { Короткострокові } \\
\text { зобов'язання } \\
\text { (протягом } \\
12 \text { місяців) }\end{array}$} & \multirow{2}{*}{$\Pi_{2}$} \\
\hline $\begin{array}{l}\text { Важко } \\
\text { ліквідні }\end{array}$ & $\mathrm{A}_{4}$ & Постійні & $\Pi_{4}$ & $\begin{array}{c}\text { Швидко } \\
\text { ліквідні активи } \\
\text { (від } 3 \text { до } \\
6 \text { місяців) } \\
\end{array}$ & $\mathrm{A}_{2}$ & & \\
\hline \multicolumn{4}{|c|}{$\begin{array}{c}\text { Модель абсолютної ліквідності } \\
\text { балансу }\end{array}$} & $\begin{array}{c}\text { Високо } \\
\text { ліквідні активи } \\
\text { (від } 0 \text { до } \\
3 \text { місяців) }\end{array}$ & $\mathrm{A}_{1}$ & $\begin{array}{c}\text { Термінові } \\
\text { зобов’язання } \\
\text { (від } 0 \text { до } \\
3 \text { місяців) }\end{array}$ & $\Pi_{1}$ \\
\hline \multirow{3}{*}{\multicolumn{4}{|c|}{$\begin{array}{c}\mathrm{A}_{1} \geq \Pi_{1} \\
\mathrm{~A}_{2} \geq \Pi_{2} \\
\mathrm{~A}_{3} \geq \Pi_{3} \\
\mathrm{~A}_{4} \leq \Pi_{4} \\
\text { Якщо одна або декілька } \\
\text { нерівностей системи мають } \\
\text { протилежний знак порівняно } 3 \\
\text { оптимальним варіантом, } \\
\text { ліквідність балансу не } \epsilon \\
\text { абсолютною }\end{array}$}} & \multicolumn{4}{|c|}{$\begin{array}{c}\text { Інтерпретація «золотого правила» } \\
\text { ліквідності для різних моделей стратегій } \\
\text { фінансування активів }\end{array}$} \\
\hline & & & & \multicolumn{2}{|c|}{$\begin{array}{c}\frac{\text { Ідеальна модель }}{\Pi_{4}+\Pi_{3}=\mathrm{A}_{4}} \\
\Pi_{2}+\Pi_{1}=\mathrm{A}_{3}+\mathrm{A}_{2}+\mathrm{A}_{1} \\
\mathrm{BOK}^{*}=0 \\
\end{array}$} & \multicolumn{2}{|c|}{$\begin{array}{c}\text { Консервативна модель } \\
\Pi_{4}+\Pi_{3}=\mathrm{A}_{4}+\mathrm{A}_{3}+\mathrm{A}_{2}+\mathrm{A}_{1} \\
\Pi_{2}+\Pi_{1}=0 \\
\text { ВОК }^{*}=\mathrm{A}_{3}+\mathrm{A}_{2}+\mathrm{A}_{1}\end{array}$} \\
\hline & & & & \multicolumn{2}{|c|}{$\begin{array}{c}\text { Агресивна модель } \\
\prod_{4}+\Pi_{3}=\mathrm{A}_{4}+\mathrm{A}_{3} \\
\prod_{2}+\Pi_{1}=\mathrm{A}_{2}+\mathrm{A}_{1} \\
\mathrm{BOK}^{*}=\mathrm{A}_{3}\end{array}$} & \multicolumn{2}{|c|}{$\begin{array}{c}\text { Компромісна модель } \\
\Pi_{4}+\Pi_{3}=\mathrm{A}_{4}+\mathrm{A}_{3}+ \\
0,5\left(\mathrm{~A}_{2}+\mathrm{A}_{1}\right) \\
\Pi_{2}+\Pi_{1}=0,5\left(\mathrm{~A}_{2}+\mathrm{A}_{1}\right) \\
\mathrm{BOK}=\mathrm{A}_{3}+0,5 \\
\left(\mathrm{~A}_{2}+\mathrm{A}_{1}\right) \\
\end{array}$} \\
\hline
\end{tabular}

* ВОК - власний оборотний капітал

Джерело: згруповано за інформацією [1, с. 87-88; 2, с. 149; 3, с. 142-144; 4, c. 121-124] 
У своїй монографії автор виділяє «золоте правило ліквідності», яке передбачає, що «... активи підприємства мають фінансуватися пасивами такої ж строковості. Оборотні активи мають фінансуватися так, щоб кредиторські заборгованості, які виникають у зв'язку 3 цим, могли бути сплачені своєчасно. Усі заборгованості підприємства по закінченню певного терміну договору мають бути виплачені» [2, с. 146]. В табл. 1 наведено порівняння класичного підходу та уніфікованого (альтернативного) підходу професора Калабухової С.В. до групування активів і пасивів балансу.

На відміну від класичного підходу пропозиції Калабухової С.В щодо групування показників балансу є більш деталізованими (в частині строковості активів і пасивів), а моделі стратегії фінансування активів мають високу аналітичність та інформативність.

Комплексне застосування статичного й динамічного підходів [1] в поєднанні з інтерпретацією «золотого правила ліквідності» [2] дадуть змогу об'єктивно оцінити реальну платоспроможність й ліквідність підприємства, створять підгрунтя для ефективного управління збалансованістю активів і пасивів за термінами, а також можуть бути використані при плануванні необхідного обсягу запасу ліквідних активів і оптимізації їхньої структури 3 урахуванням швидкості обертання зобов'язань. Отже, сучасні підходи провідних науковців щодо аналізу ліквідності підприємства забезпечать отримання об'єктивної, багатогранної, точної, достовірної інформації. А їх практичне використання сприятиме виявленню потенційних можливостей зміни й розвитку ліквідності та платоспроможності підприємств, притаманних їм явищ і процесів, попередженню та нейтралізації відхилень від норм, диспропорцій, структурних деформацій, несприятливих і ризикових ситуацій.

\section{Література:}

1. Парасій-Вергуненко I.M. Статичний і динамічний підходи до аналізу ліквідності та платоспроможності суб'єктів господарювання. Фінанси України. 2017. Вип. 2. С. 81-95. 
2. Калабухова С.В. Уніфікація аналітичних процедур в умовах стандартизації бухгалтерського обліку та аудиту: монографія. Київ : КНЕУ, 2019. $431 \mathrm{c.}$

3. Тютюнник Ю.М., Дорогань-Писаренко Л.О., Тютюнник С.В. Фінансовий аналіз: навч. посіб. Полтава : Видавництво ПП «Астрая», 2020. 434 с.

4. Лучко М.P., Жукевич С.М., Фаріон А.І. Фінансовий аналіз: навч. посіб. Тернопіль : ТНЕУ, 2016. 304 с. 